\title{
EFFECT OF THE TRANSATMOSPHERIC SUN ELECTROMAGNETIC RADIATION, SIMULATED LABORATORY, ON THE MECHANICAL PROPERTIES OF THE KAPTON H TYPE POLYIMIDE FILMS
}

\author{
(DViktory A. Lototskaya ${ }^{1 *}$, Deonid F. Yakovenko1, (D)Evgeniy N. Aleksenko', \\ (D) Nikolay I. Velichko', (D)Yuriy S. Doronin', (DAnna A. Tkachenko', \\ (DIvan P. Zaritskiy ${ }^{1}$, Vyacheslav V. Abraimov ${ }^{2}$, Wen Zhu Shao ${ }^{2}$ \\ ${ }^{1} B$. Verkin Institute for Low Temperature Physics and Engineering of NAS of Ukraine \\ Prospect Nauky, 47, Kharkov, 61103, Ukraine \\ ${ }^{2}$ Harbin Institute of Technology \\ Harbin, the People's Republic of China \\ *E-mail: lototskaya@ilt.kharkov.ua
}

Received August 27, 2019; revised September 17, 2019, accepted Ocober 21, 2019

\begin{abstract}
The mechanical properties (limit of forced elasticity, fracture stress, total deformation to failure and its components) of a $75 \mu \mathrm{m}$-thick polyimide film of kapton $\mathrm{H}$ type under uniaxial tension conditions at $293 \mathrm{~K}$ after exposure to the outer space factors were studied. The electromagnetic radiation of the transatmospheric Sun in the wavelength range of 250-2500 nm (EMRS) for 100 hours and vacuum ultraviolet (VUV) and ultra soft x-ray (USX) radiation in the range of 1.24-170 nm - for 100 and 500 hours were simulated under laboratory conditions. The effect of separate exposure in each of the wavelength ranges was investigated. It was found that after irradiation in the both wavelength ranges the films remained in a forced-elastic state. The tension diagrams, like in the initial state, have two stages. The contributions of the elastic, irreversible and highly elastic (delayed and reversible at test temperature) components to the total deformation to failure were determined. It was found that the limit of forced elasticity increased after irradiation both with EMRS, and with VUV and USX radiation. In this case an increase in the limit of the forced elasticity under the influence of EMRS was caused by heating of the film in the course of irradiation, and under the influence of VUV and USX radiation - by radiation effects. The fracture stress and total deformation to failure change weakly and only under the influence of VUV and USX radiation. With changing the duration of exposure to VUV and USX radiation (100 or 500 hours), the fracture stress and the total deformation to failure change non-monotonously. The negative consequence of exposure to VUV and USX radiation is the contribution values redistribution of the individual components of the total deformation to failure. VUV and USX radiation within 500 hours leads to a halving of the contribution of elastic deformation, which is reversible at deformation temperature.
\end{abstract}

KEY WORDS: polyimides, space factors, limit of forced elasticity, fracture stress, deformation

For several decades polyimide with the monomeric unit $\mathrm{C}_{22} \mathrm{H}_{10} \mathrm{~N}_{2} \mathrm{O}_{5}$ (of kapton $\mathrm{H}$, PM-A type, etc.) has been the main ultra-lightweight radiation-resistant polymer, used as a heat insulator on the outer surface of spacecrafts (SC). During this period the researchers' attention, primarily, was paid to the influence of space factors on the polymer electrical and thermo-radiation properties. In the process of development and design of small-sized satellites with an increased "lifetime" in orbit, a great interest arose to the mechanical properties of the polymer. In the outer space a number of extraordinary factors act simultaneously and alternately on the materials and elements of the spacecrafts: high vacuum, electromagnetic radiation, charged particle fluxes, thermal cycling, etc. In our previous work [1] we considered the influence of protons and electrons of the Earth's radiation belts with a length free path, comparable with the thickness of the film, on its mechanical properties under uniaxial tension. The obtained results on changing the limits of the forced elasticity, fracture stress, and overall elongation are in good agreement with the results given in the review [2]. The data on redistribution of different contributions to the total deformation (contributions of highly elastic, reversible at test temperature, delayed highly elastic and irreversible deformation) are presented only in our work.

The object of this work is to study the patterns of deformation and strength of kapton H-type polyimide films after simulating the separate effects of electromagnetic radiation from the transatmospheric Sun in the ranges of 250-2500 $\mathrm{nm}$ and $1.24-170 \mathrm{~nm}$.

\section{MATERIAL AND METHOD OF RESEARCH}

The objects of study were samples of thermoplastic film of aromatic polyimide - poly-4,4'-diphenylene oxide pyromellitimide, manufactured by PRC (People's Republic of China), with the thickness of $75 \mu \mathrm{m}$. The mechanical properties of this film in its initial state and after its exposure to fluxes of corpuscular radiation were studied in $[1,3]$.

Samples for testing under uniaxial tension (Fig. 1) were obtained using a special die. The axis of tension coincided with the direction of the film drawing. The shape and dimensions of the sample are close to type 1 according to State Standard 11262, which is admitted for use in tensile tests of film polymer samples (State Standard 14236). The sample was fixed with special grippers. The gripper consists of a roller, around which the sample blade is bent, and two clamps that capture the roller with the blade.

The mechanical properties of the samples subjected to space factors (SF) were studied at room temperature in the open air $(293 \mathrm{~K})$ not later than 24 hours after irradiation. The samples deformation under uniaxial tension was (C) Viktory A. Lototskaya, Leonid F. Yakovenko, Evgeniy N. Aleksenko, Nikolay I. Velichko, Yuriy S. Doronin,

Anna A. Tkachenko, Ivan P. Zaritskiy, Vyacheslav V. Abraimov, Wen Zhu Shao, 2019 
performed using FPZ-100/1 tensile testing machine with a low-temperature unit, created in the Institute for Low Temperature Physics and Engineering [4], with the active rod moving speed $\mathrm{V}_{\text {def. }}=0.85 \mathrm{~mm} / \mathrm{min}$ and, correspondingly, with the deformation rate $\dot{\varepsilon}=7 \cdot 10^{-4} \mathrm{~s}^{-1}$ ( $\dot{\varepsilon}=\mathrm{V}_{\text {def }} / \mathrm{L}_{\mathrm{o}}$, where $\mathrm{L}_{\mathrm{o}}$ is the initial working length of the sample).

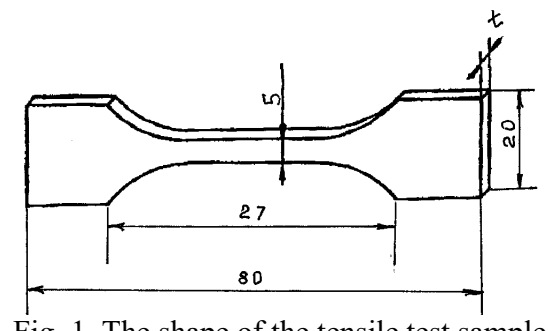

Fig. 1. The shape of the tensile test sample

In the process of deformation a tensile diagram was recorded in the coordinates "load P-elongation $\Delta \mathrm{L}$ ", from which the following mechanical characteristics were determined: the apparent limit of forced elasticity, corresponding to the stress, at which the highly elastic deformation is $1 \%, \sigma_{\text {forc. }}=\mathrm{P}_{1 \%} / \mathrm{S}_{0}$; fracture stress of the sample $\sigma_{\text {fr. }}=\mathrm{P}_{\text {frr }} / \mathrm{S}_{0}$, where $\mathrm{S}_{\mathrm{o}}$ is the initial cross section of the sample; total elongation $\Delta \mathrm{L}_{\text {total }}$, corresponding to the moment of the sample fracture; elongation $\Delta \mathrm{L}_{\text {elast. }}$, corresponding to the elastic section of the curve. The other contributions to the total deformation $\Delta \mathrm{L}_{\text {total }}=\Delta \mathrm{L}_{\text {elast. }}+\Delta \mathrm{L}_{\text {high el.1 }}+\Delta \mathrm{L}_{\text {high el.2 }}+\Delta \mathrm{L}_{\text {irrevers. }}$ were determined as in [3]. All these mechanical characteristics are presented below as average values according to the test results of six samples in each state.

The surface fractures of the samples were studied using MBS-9 optical microscope. In addition the surface fractures of the film samples, deformed in the initial state at $77 \mathrm{~K}$, were analyzed. Mechanical properties of these samples are presented in [3].

The studied polyimide films were affected by SF (simulated in the laboratory) in a complex simulator of 8 space factors CSSF (Fig. 2), developed at the Institute for Low Temperature Physics and Engineering of NAS of Ukraine, which was described in detail in [5], and briefly - in [1].

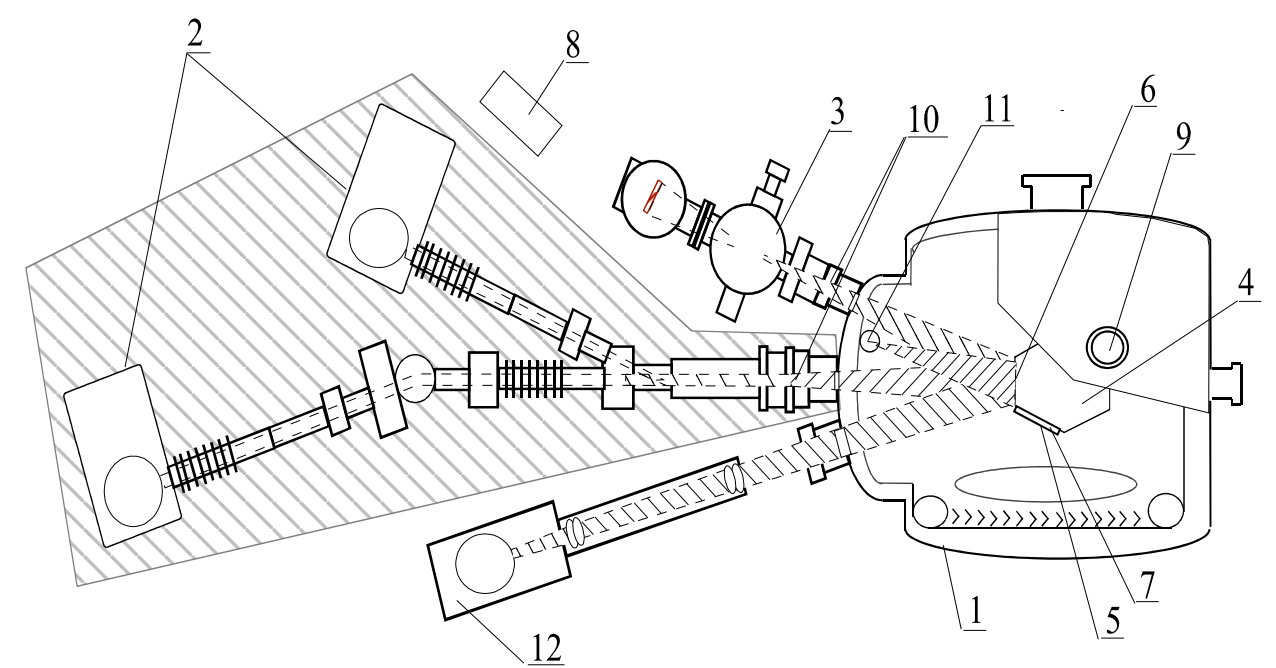

Fig. 2. Scheme of CSSF simulator

1 - cryogenic vacuum chamber; 2 - proton-electron accelerator on combined beams; 3 - gas-jet source of VUV and USX radiation; 4 - drum; 5 - zone for sample installation; 6 - zone of radiation factors effect on the sample; 7 - sample holder board; 8 - control system rack; 9 - electric vacuum connector; 10 - vacuum slide shutters; 11 - gas-discharge radiation source (GDRS); 12 - IS-160.

To simulate the electromagnetic radiation of the transatmospheric Sun (hereinafter EMRS) in the wavelength range $\lambda=200-2500 \mathrm{~nm}$ with the radiation intensity $\mathrm{J}_{\mathrm{S}}=0.14 \div 0.28 \mathrm{~W} / \mathrm{cm}^{2}$ and the irradiation area $\mathrm{S}=100 \mathrm{~cm}^{2}$, a simulator of the transatmospheric Sun of CSSF type IS-160 is used (pos.12, Fig.2). In this investigation the samples were exposed to EMRS in the range of $250-2500 \mathrm{~nm}$ for 100 hours without cooling the chamber jacket with liquid nitrogen, what corresponded to 100 hours of solar irradiation on the near Earth orbit. The target temperature at irradiation under these conditions was $94^{\circ} \mathrm{C}$. Heating in the process of irradiation was simulated separately on 6 samples, which were annealed in the open air in a muffle furnace at this temperature for 100 hours.

Simulation of the effect of vacuum ultraviolet (VUV) and ultra-soft X-ray (USX) radiation in the range of 1.24-170 nm was provided by a gas-jet source GJS (pos.3, Fig.2), developed at the Institute for Low Temperature Physics and Engineering [6,7]. The gas-jet method for generation of electromagnetic radiation is based on the excitation of the supersonic jet of a gas mixture in the vacuum by an electron beam. This method allows introducing VUV and USX radiation into the high-vacuum chamber of the CSSF simulator $\left(10^{-5} \mathrm{~Pa}\right)$ in a wide space angle without using 
optical windows (Fig. 3). In this case the irradiation of the test object, located in the high-vacuum CSSF chamber at the distance of $70 \mathrm{~cm}$ from the axis of the jet, can vary from 2 to 10 -fold excess of solar irradiation in the Earth orbit. The GJS source radiation spectrum is as close as possible to the solar radiation spectrum in the specified wavelength range [6].

To reduce the experiment time, the irradiated films were placed not on the CSSF target, but directly in the GJS source chamber, what allowed increasing the irradiancy on the samples to $2 \cdot 10^{-4} \mathrm{~W} / \mathrm{cm}^{2}$. Two doses of the samples irradiation with VUV and USX radiation, corresponding to 100 and 500 hours of solar irradiancy on the Earth orbit, were chosen.

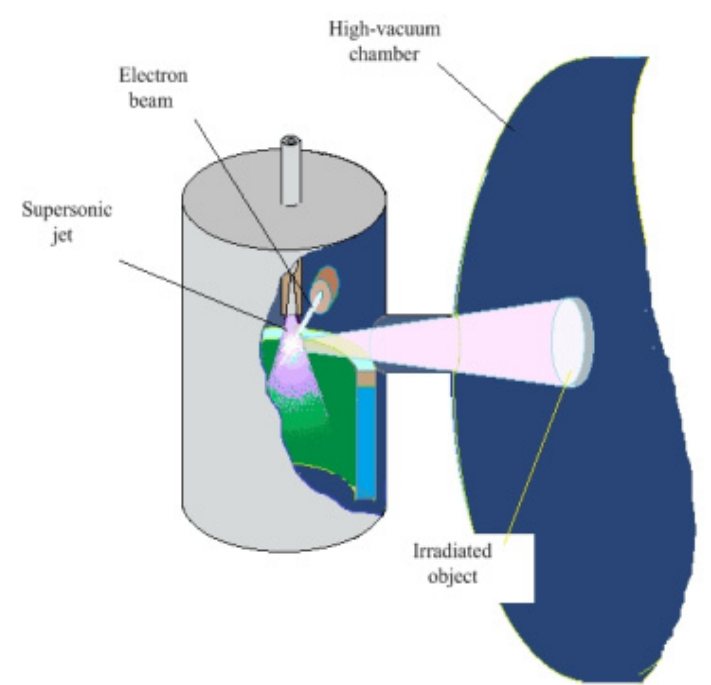

a)

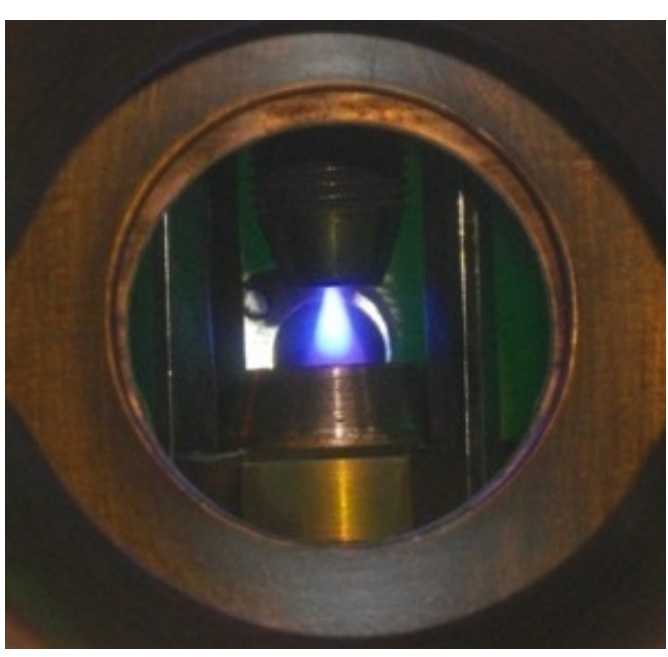

b)

Fig. 3 GJS - gas-jet simulator of the Sun

a) schematic representation of the gas-jet method for generating electromagnetic radiation and introducing it into the highvacuum chamber, b) semi-cryogenic version of the VUV and USX radiation simulator of the Sun as a part of the CSSF simulator.

\section{RESULTS OF EXPERIMENTS AND THEIR DISCUSSION}

Fig. 4 shows typical curves "stress $(\sigma)$-deformation $(\varepsilon)$ " of polyimide film samples in the states under study: $(1)-$ initial, (2) - after EMRS irradiation, (3) - after heating in a muffle furnace, (4 and 5) - after irradiation with VUV and USX radiation during to 100 (4) and 500 (5) hours. The $\sigma-\varepsilon$ curves of the samples, both in the initial state and after all types of exposure, have two stages - linear and nonlinear. At the linear stage, only elastic deformation $\varepsilon_{\text {elast. }}$ occurs and the $\sigma-\varepsilon$ diagram during loading and unloading is the same (Fig. 4). In the process of unloading, from the beginning of the second stage of deformation a hysteresis of the $\sigma(\varepsilon)$ curve trend is observed, and a part of the deformation is a reversible highly elastic one $\varepsilon_{\text {high el.1. }}$. With further loading, the contributions of the delayed highly elastic $\varepsilon_{\text {high el.2 }}$ and irreversible $\varepsilon_{\text {irrevers. }}$ deformation also occur (Fig. 5). The last mentioned contribution does not disappear at heating to the temperature $\mathrm{T}<\mathrm{T}_{\text {soft. }}$ in the range of the polymer softening temperature $\mathrm{T}_{\text {soft. }}$.

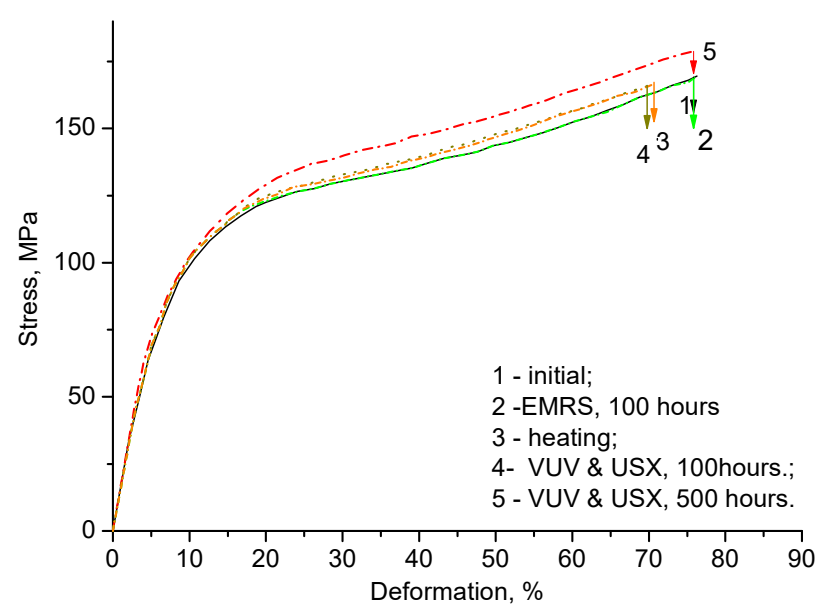

Fig. 4. Typical curves "stress $(\sigma)$ - deformation $(\varepsilon) "$ of a polyimide film 75 microns thick

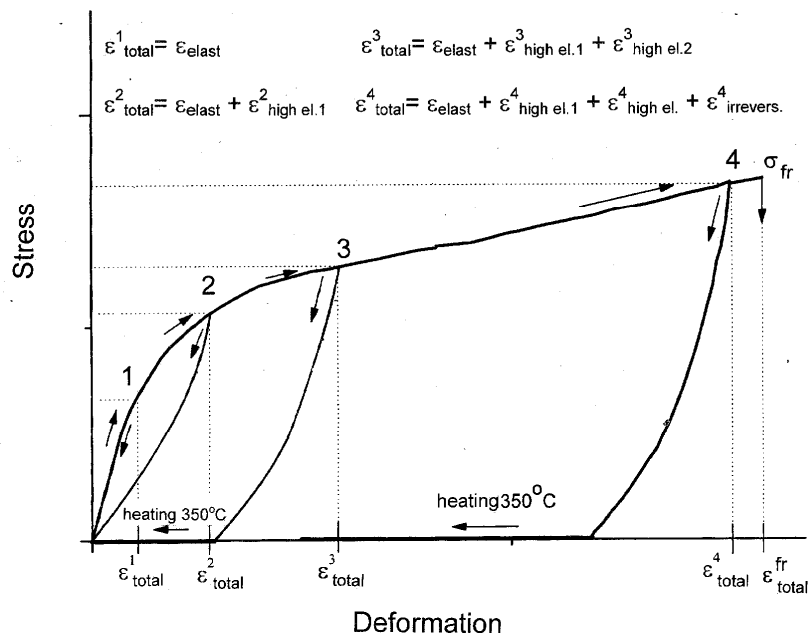

Fig. 5. The curve of deformation under loading and unloading of an irradiated film deformed to some loading values $(1,2,3,4)$ at $293 \mathrm{~K}$ 
The deformation curves $\sigma-\varepsilon$ of the film after all types of exposure differ little (Fig. 4). Only $\sigma-\varepsilon$ curves of the films, exposed to VUV and USX radiation for 500 hours, show higher stress values all over the curve. After the other types of exposure, the strengthening effect was found only at the limit of the forced elasticity $\sigma_{\text {forc. }}$. Figure 6 presents histograms with average values of the limit of forced elasticity $\sigma_{\text {forc }}$, fracture stress $\sigma_{\text {frr. }}$, and the total deformation $\varepsilon_{\text {total }}$ of the initial and irradiated samples. The $\sigma_{\text {forc }}$ limit increases after exposure to SF by an average of $14 \%$ (EMRS), and by $17 \%$ (VUV and USX). However, under exposure to EMRS, the heating of the target was observed, which was absent under exposure to VUV and USX radiation. Heating of the samples at the temperature corresponding to the target one $\left(94^{\circ} \mathrm{C}\right)$ for the same 100 hours of exposure causes a similar increase in the value of $\sigma_{\text {forc. }}$, therefore we associate hardening when simulating the effect of EMRS only with heating of the sample on the target. The fracture stress $\sigma_{\mathrm{fr}}$ and total deformation $\varepsilon_{\text {total }}$ after exposure to EMRS remain at the same level as in the initial samples.

After exposure to VUV and USX radiation, the values of these characteristics $\left(\sigma_{\mathrm{fr} .}, \varepsilon_{\text {total }}\right)$ also change slightly, but ambiguously at different duration of irradiation. It was found that after 100 hours of irradiation, the average values of the both characteristics were slightly lower than the initial ones (by 7\%), and after 500 hours of exposure the average values of the fracture stress became $5 \%$ higher than the initial ones, and the total elongation value was equal to that in the initial samples.

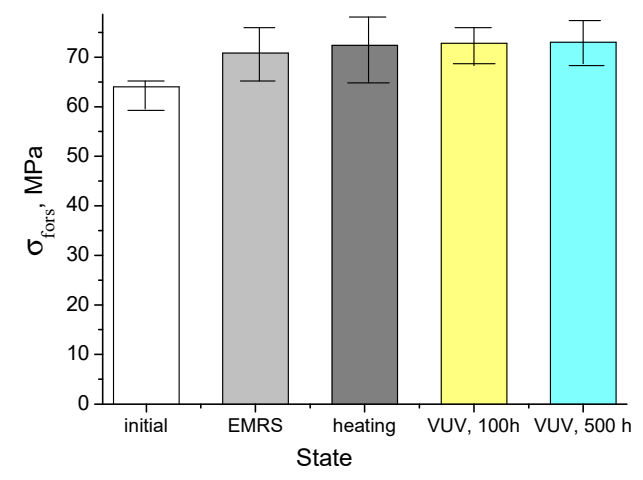

a)

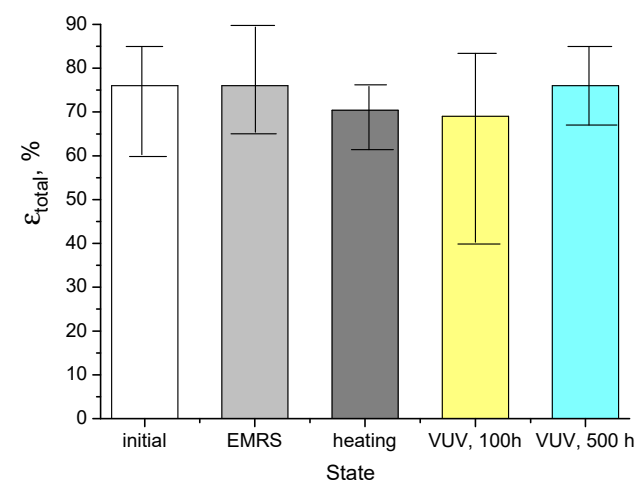

c)

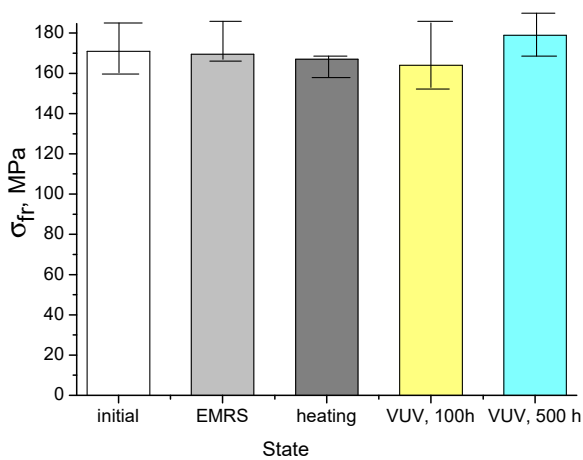

b)
Fig. 6. Average values of mechanical characteristics: a) - forced elasticity limit, b) - fracture stress c) - total deformation to failure of the polyimide film samples at room temperature in the initial state and after their exposure to SF

The average values of total deformation $\varepsilon_{\text {total }}$ and its individual components (highly elastic deformation $\varepsilon_{\text {high el.1 }}$, reversible at the test temperature, total forced highly elastic deformation: reversible $\varepsilon_{\text {high el.1 }}+$ delayed $\varepsilon$ high el.2 and irreversible deformation $\varepsilon_{\text {irrevers. }}$ ) of the samples, tested in the initial state and after their exposure to SF, are given in Fig. 7. It is seen that EMRS effect does not cause any significant redistribution of the values of the total deformation components. $10 \%$-decrease in the contribution of the irreversible deformation $\varepsilon_{\text {irrevers. }}$ after exposure to EMRS, as well as after annealing in a muffle furnace, can be due to heating of the target. Exposure to VUV and USX radiation leads to an unambiguous decrease in the contribution of the highly elastic deformation $\varepsilon$ high el.1, reversible at the test temperature, which reached $50 \%$ after 500 hours of irradiation. It should be also noted, that a large spread of $\varepsilon_{\text {irrevers. }}$ values in the samples exposed to irradiation for 100 hours can be observed.

In contrast to the samples, that were exposed to corpuscular radiation [1], no twisting was detected in the samples deformed to failure and, hence, no macrostresses in them. However, in the samples exposed to VUV and USX radiation, a change in the nature of the samples fracture was detected (Fig. 8).

The initial films destruction at $293 \mathrm{~K}$ (Fig.8a) arises due to tearing off transversely to the tensile axis of the sample with a slim neck. At the temperature of $77 \mathrm{~K}$ (Fig.8b) in the initial film fractures some zones of slight tear and tension bars are observed, what indicates to some embrittlement of the films. A similar picture is observed in the fractures of films exposed to VUV and USX irradiation. 
Summarizing the results, we should note that our experiments confirm high radiation resistance of the polyimide films of kapton $\mathrm{H}$ type to the electromagnetic solar radiation. However, it should be emphasized, that despite the small content $\left(10^{-3} \%\right)$ of VUV and USX radiation with respect to the total energy of the Sun, its effect on the mechanical properties of polyimide is most evident. While the increase in the limit of the forced elasticity after exposure to EMRS in the range of 250-2500 nm is due only to heating, an increase in $\sigma_{\text {forc. }}$, as well as a decrease in the contribution of the reversible highly elastic deformation and embrittlement of the fractures after irradiation with VUV and USX radiation in the absence of heating, are associated only with radiation exposure. According to $[2,8]$ two competing processes, i.e. rupture of macrochains and intermolecular linking, can occur under irradiation. For a more detailed determination of the physical mechanisms of the processes, some spectroscopic studies are required.

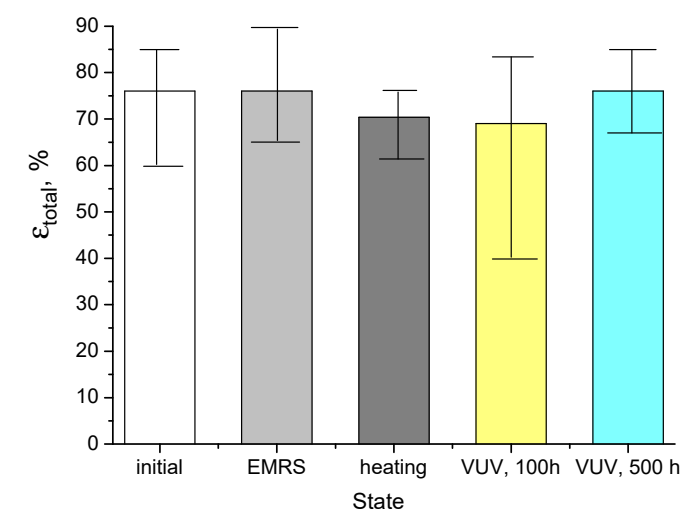

a)

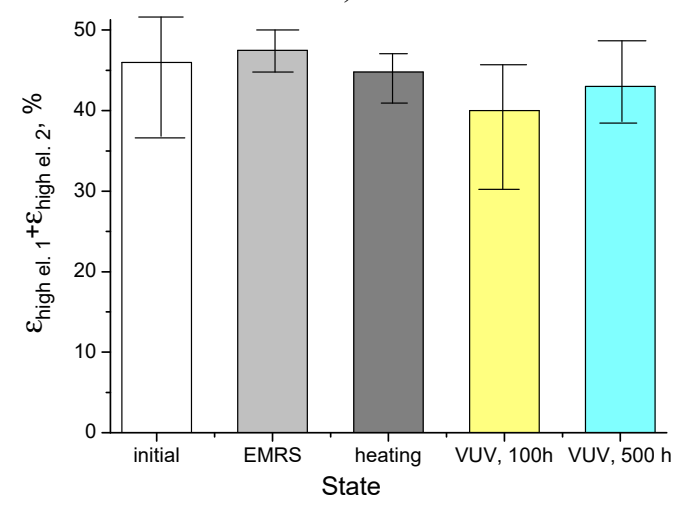

c)

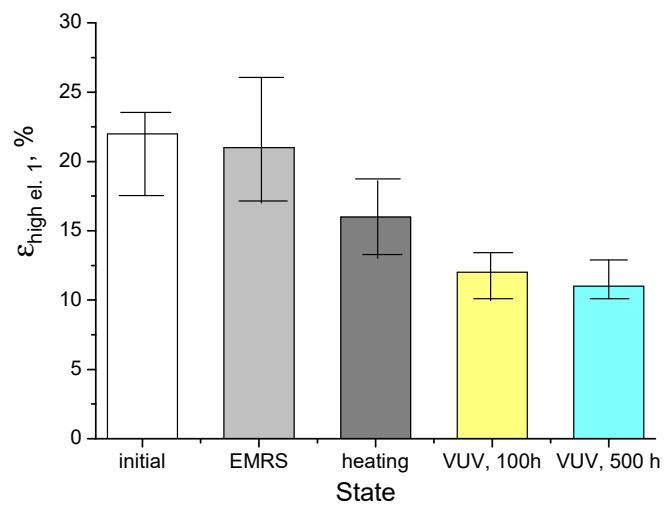

b)

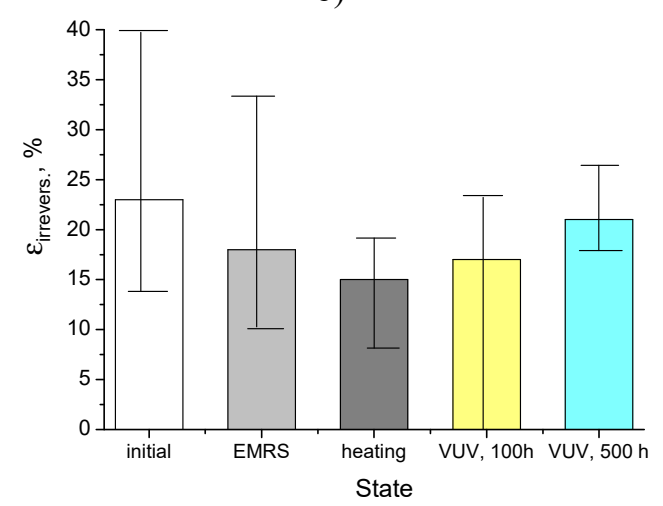

d)

Fig. 7. Average values of the total deformation and its components for the polyimide film samples deformed at $\mathrm{T}=293 \mathrm{~K}$ in the initial state and after exposure to SF.

a) - total deformation to failure of the samples $\varepsilon_{\text {total }}, \mathrm{b}$ ) - highly elastic reversible deformation at the test temperature, $\left.\varepsilon_{\text {high el.1, }}, \mathrm{c}\right)-$ total forced highly elastic deformation $\left(\varepsilon_{\text {high el..1 }}+\varepsilon_{\text {high el. 2), d) }}\right.$ - irreversible deformation $\varepsilon_{\text {irrevers. }}$

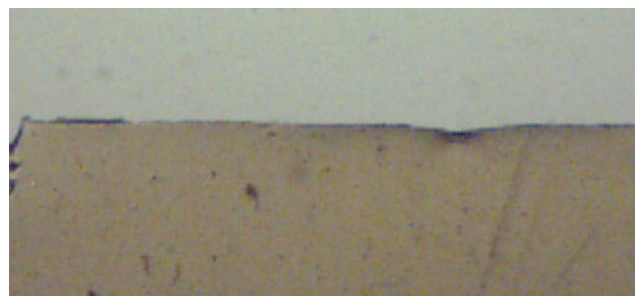

a)

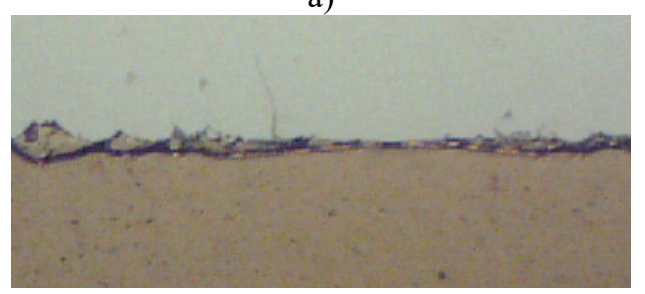

c)

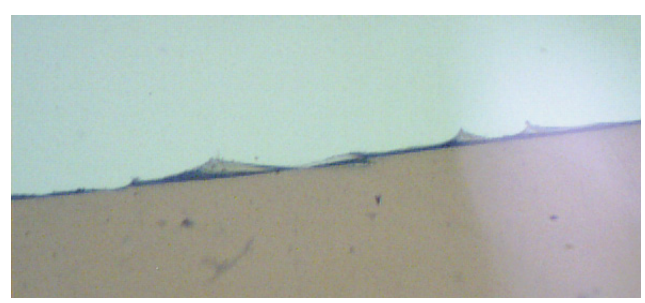

b)

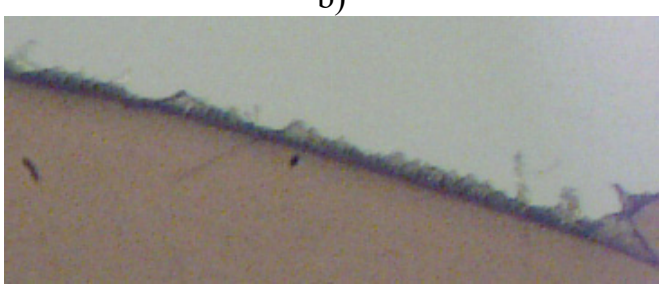

d)

Fig. 8. Areas of destruction of the initial (a, b) and exposed to VUV and USX radiation for 100 hours (c), and for 500 hours (d) samples after deformation at the rate $\dot{\varepsilon}=7 \cdot 10^{-4} \mathrm{~s}^{-1}$ at the temperature $\mathrm{T}=293 \mathrm{~K}$ (a, c, d), and $\mathrm{T}=77 \mathrm{~K}$ (b). 
It should be also noted, that the increase in the forced elasticity limit after exposure to VUV and USX radiation for not more than 500 hours, corresponds to the level of increase in this characteristic after exposure to protons with the energy of $160 \mathrm{keV}$, when simulating a spacecraft flight for 100 years in the ISS orbit at $\mathrm{H}=400 \mathrm{~km}$, and a spacecraft flight on the geostationary orbit at $\mathrm{H}=36000 \mathrm{~km}$ for 10 years. From the applied point of view, an increase in the level of the forced elasticity limit is of great importance. At the same time, a decrease in the level of reversible highly elasticity of films after exposure to VUV and USX radiation is a negative factor, especially under cyclic loading.

\section{CONCLUSION}

1. It is shown, that kapton H-type polymer film under study is characterized by high radiation resistance to electromagnetic radiation from the transatmospheric Sun in the wavelength ranges of 250-2500 nm and 1.24-170 $\mathrm{nm}$.

2. It is found, that an increase in the forced elasticity limit $\sigma_{\text {forc. }}$ by $14 \%$ after exposure to EMRS in the wavelength range of 250-2500 $\mathrm{nm}$ is due to the influence of film heating under irradiation.

3. An increase in the forced highly elasticity limit $\sigma_{\text {forc }}$ by $17 \%$ was detected after exposure to VUV and USX electromagnetic radiation in the range of different time (100 and 500 hours), which did not relate to heating.

4. The fracture stress $\sigma_{\text {fr. }}$ and the total deformation to failure $\varepsilon_{\text {total }}$ after all types of exposure vary slightly, but nonmonotonously after different time of exposure to VUV and USX radiation. After exposure for 100 hours, both characteristics are slightly reduced (by 7\%), and after irradiation for 500 hours $\varepsilon_{\text {total }}$ returns to its almost original state, and $\sigma_{\text {fr. }}$ increases slightly (by $5 \%$ ).

5. It is ascertained, that with a slight change in $\varepsilon_{\text {total }}$ after exposure to VUV and USX radiation, a significant redistribution of the values of its components occurs. The largest decrease (by 50\%) is demonstrated by the contribution of highly elastic deformation $\varepsilon_{\text {high el.1, }}$, reversible at the test temperature.

6. From the applied point of view, it is important to increase the level of the forced elasticity limit after exposure to electromagnetic radiation within all the wavelength range under study with a slight change in other macroscopic mechanical characteristics. A negative factor, especially under cyclic loading, is a decrease in the level of reversible elasticity of films after their exposure to VUV and USX radiation.

\section{ORCID IDs}

DViktory A. Lototskaya https://orcid.org/0000-0001-8766-3154, (DLeonid F. Yakovenko https://orcid.org/0000-0003-0001-5571, (D)Evgeniy N. Aleksenko https://orcid.org/0000-0002-6505-0426, DIvan P. Zaritskiy https://orcid.org/0000-0003-2414-946X (D) Yuriy S. Doronin https://orcid.org/0000-0001-8860-7656, (D)Anna A. Tkachenko https://orcid.org/0000-0002-1385-2857

Dikolay I. Velichko https://orcid.org/0000-0003-0021-9849

\section{REFERENCES}

[1] V.A. Lototskaya, L.F. Yakovenko, E.N. Aleksenko, N.I. Velichko, I.P. Zaritskiy, V.V. Abraimov, Wen Zhu Shao and Liu Hai, East. Eur. J. Phys. 3, 53-60 (2018), https://doi.org/10.26565/2312-4334-2018-3-06.

[2] E.A. Plis, D.P. Engelhart, R. Cooper, W.R. Johnston, D. Ferguson and R. Hoffman, Appl. Sci. 9, 1999-2022 (2019), https://doi.org/10.3390/app9101999.

[3] V.A. Lototskaya, L.F. Yakovenko, E.N. Aleksenko, V.V. Abraimov and Wen Zhu Shao, East. Eur. J. Phys. 2, 44-52 (2017), https://doi.org/10.26565/2312-4334-2017-2-06.

[4] L.M. Volikova and V.K. Chernetskiy, in: Прикладне кріогенне і вакуумне матеріалознавство [Applied cryogenic and vacuum material science] (Naukova dumka, Kyiv, 1991), pp. 137-143. (in Russian)

[5] V.V. Abraimov, A.A. Negoda, A.P. Zavalishin and L.K. Kolybaev, Space Science and Technology, 1(2), 76-80 (1995), https://doi.org/10.15407/knit1995.02.076. (in Russian)

[6] E.A. Bondarenko, Yu.S. Doronin, E.T. Verkhovtseva, E.V. Gnatchenko and A.A. Tkachenko, in: IVth Intern. Conf. on Laboratory Research for Planetary Atmospheres: Program of Invited Papers and Contributed Posters. (Munich, 1992), pp. 26.

[7] E.T. Verkhovtseva, V.I. Yaremenko and V.D. Telepnev, Space Science and Technology, 4(2), 102-109 (1998), https://doi.org/10.15407/knit1998.02.102 (in Russian)

[8] M.I. Bessonov, M.M. Koton, V.V. Kudryavtsev and L.A. Layus, Полиимиды - класс термостойких полимеров [Роlyimides - class of heat-resistant polymers] (Nauka, Leningrad, 1984), pp. 328. (in Russian)

\section{ВПЛИВ ЕЛЕКТРОМАГНІТНОГО ВИПРОМІНЮВАННЯ ЗААТМОСФЕРНОГО СОНЦЯ, ЩО ІМТОВАНО ЛАБОРАТОРНО, НА МЕХАНІЧНІ ВЛАСТИВОСТІ ПОЛІМІДНОӤ ПЛІВКИ ТИПУ КАРТОN Н \\ Вікторія О. Лотоцька ${ }^{1}$, Леонід Ф. Яковенко ${ }^{1}$, Свген М. Алексенко $^{1}$, Микола І. Величко ${ }^{1}$, Юрій С. Доронін ${ }^{1}$, Ганна О. Ткаченко ${ }^{1}$, Іван П. Заріцький ${ }^{1}$, В'ячеслав В. Абраімов ${ }^{2}$, Wen Zhu Shao ${ }^{2}$ \\ ${ }^{1}$ Фізико-технічний інститут низьких температур ім. Б.І. Вєркіна НАН Украӥни пр. Науки, 47, м. Харків, 61103, Україна \\ ${ }^{2}$ Харбінський Політехнічний інститут, м. Харбін, КНР}

Досліджено механічні властивості (границя вимушеної еластичності, напруга руйнування, загальна деформація до руйнування і iї складові) поліімідної плівки типу kapton $\mathrm{H}$ товщиною 75 мкм в умовах одновісного розтягування при температурі 293 К після впливу факторів космічного простору. Лабораторно імітували електромагнітне випромінювання заатмосферного Сонця в діапазоні довжин хвиль 250-2500 нм (ЕМВС) протягом 100 годин і вакуумне ультрафіолетове (ВУФ) і ультрам'яке рентгенівське (УМР) випромінювання в діапазоні 1,24-170 нм протягом 100 і 500 годин. Досліджували вплив роздільного опромінення в кожному 3 діапазонів довжин хвиль. Виявлено, що після опромінення в обох діапазонах 
довжин хвиль плівки залишаються в вимушеноеластічному стані. Діаграми розтягування, як і в початковому стані, мають дві стадії. Визначено вклади пружної, незворотної і високоеластичної (затриманої і оборотної при температурі випробування) складових в загальну деформацію до руйнування. Виявлено, що границя вимушеної еластичності зростає, як після опромінення ЕМВС, так і ВУФ і УМР випромінюванням. При цьому підвищення границі вимушеної еластичності під дією ЕМВС викликано нагрівом плівки під час опромінення, а під впливом ВУФ- і УМР випромінювання - радіаційними ефектами. Напруга руйнування і загальна деформація до руйнування змінюються слабо і лише під дією ВУФ і УМР випромінювання. При зміні тривалості опромінення ВУФ і УМР випромінювання (100 або 500 годин) напруга руйнування $\mathrm{i}$ загальна деформація до руйнування змінюються немонотонно. Негативним наслідком впливу ВУФ і УМР випромінювання $\epsilon$ перерозподіл величин вкладів окремих складових сумарної деформації. Випромінювання протягом 500 год. призводить до зниження в два рази вкладу еластичної деформації, оборотної при температурі деформації.

КЛЮЧОВІ СЛОВА: полііміди, фактори космічного простору, границя змушеної еластичності, напруга руйнування, деформація

\author{
ВЛИЯНИЕ ЭЛЕКТРОМАГНИТНОГО ИЗЛУЧЕНИЯ ЗААТМОСФЕРНОГО СОЛНЦА, ИМИТИРУЕМОГО \\ ЛАБОРАТОРНО, НА МЕХАНИЧЕСКИЕ СВОЙСТВА ПОЛИИМИДНОЙ ПЛЕНКИ ТИПА КАРТОN Н \\ Виктория А. Лотоцкая ${ }^{1}$, Леонид Ф. Яковенко ${ }^{1}$ Евгений Н. Алексенко ${ }^{1}$, Николай И. Величко ${ }^{1}$, Юрий С. Доронин ${ }^{1}$, \\ Анна А. Ткаченко ${ }^{1}$, Иван П. Зарицкий ${ }^{1}$, Вячеслав В. Абраимов ${ }^{2}$, Wen Zhu Shao ${ }^{2}$ \\ ${ }^{I}$ Физико-технический институт низких температур им. Б.И.Веркина НАН Украинь \\ пр. Науки, 47, г. Харьков, 61103, Украина \\ ${ }^{2}$ Харбинский Политехнический институт, г. Харбин, КНР
}

Исследованы механические свойства (предел вынужденной эластичности, напряжение разрушения, общая деформация до разрушения и ее составляющие) полиимидной пленки типа kapton $\mathrm{H}$ толщиной 75 мкм в условиях одноосного растяжения при температуре $293 \mathrm{~K}$ после воздействия факторов космического пространства. Лабораторно имитировали электромагнитное излучение заатмосферного Солнца в диапазоне длин волн 250-2500 нм (ЭМИС) в течение 100 часов и вакуумное ультрафиолетовое (ВУФ) и ультрамягкое рентгеновское (УМР) излучение в диапазоне 1,24-170 нм в течение 100 и 500 час. Исследовали влияние раздельного облучения в каждом из диапазонов длин волн. Обнаружено, что после облучения в обоих диапазонах длин волн пленки остаются в вынужденноэластическом состоянии. Диаграммы растяжения, как и в исходном состоянии, имеют две стадии. Определены вклады упругой, необратимой и высокоэластической (задержанной и обратимой при температуре испытания) составляющих в общую деформацию до разрушения. Обнаружено, что предел вынужденной эластичности возрастает, как после облучения ЭМИС, так и после воздействия ВУФ и УМР излучением. При этом повышение предела вынужденной эластичности под действием ЭМИС вызвано нагревом пленки в процессе облучения, а под воздействием ВУФ и УМР излучения - радиационными эффектами. Напряжение разрушения и общая деформация до разрушения изменяются слабо и только под действием ВУФ и УМР излучения. При изменении длительности облучения ВУФ и УМР излучения (100 или 500 час.) напряжение разрушения и общая деформация до разрушения изменяются немонотонно. Негативным последствием воздействия ВУФ и УМР излучения является перераспределение величин вкладов отдельных составляющих суммарной деформации. Облучение в течение 500 час. приводит к снижению в два раза вклада эластической деформации, обратимой при температуре деформации.

КЛЮЧЕВЫЕ СЛОВА: полиимиды, факторы космического пространства, предел вынужденной эластичности, напряжение разрушения, деформация 